Relations industrielles

Industrial Relations

\title{
Keith BRADLEY, Alan GELB : Worker Capitalism. The New Industrial Relations. Cambridge, The MIT Press, 1983, 186 pp., ISBN 0-262-02191-0
}

\section{Clive Gilson}

Volume 40, numéro 3, 1985

URI : https://id.erudit.org/iderudit/050170ar

DOI : https://doi.org/10.7202/050170ar

Aller au sommaire du numéro

\section{Éditeur(s)}

Département des relations industrielles de l'Université Laval

\section{ISSN}

0034-379X (imprimé)

1703-8138 (numérique)

Découvrir la revue

Citer ce compte rendu

Gilson, C. (1985). Compte rendu de [Keith BRADLEY, Alan GELB : Worker Capitalism. The New Industrial Relations. Cambridge, The MIT Press, 1983, 186 pp., ISBN 0-262-02191-0]. Relations industrielles / Industrial Relations, 40(3), 678-680. https://doi.org/10.7202/050170ar

Tous droits réservés (C) Département des relations industrielles de l'Université Laval, 1985
Ce document est protégé par la loi sur le droit d'auteur. L'utilisation des services d'Érudit (y compris la reproduction) est assujettie à sa politique d'utilisation que vous pouvez consulter en ligne.

https://apropos.erudit.org/fr/usagers/politique-dutilisation/ 
manente des droits de négociation, ils suggèrent deux réactions possibles des syndicats: d'abord, un accroissement des grèves parmi les cols bleus alors que, règle générale, les cols bleus accepteront plus facilement la nouvelle réalité, tout en se prévalant plus souvent des mécanismes d'appel disponibles (s'il en reste); cependant, certains cols blancs adopteront eux aussi des tactiques militantes; ensuite, le rôle des administrations locales va devenir de plus en plus marginal au fur et à mesure que les politiciens s'impliqueront personnellement dans les relations du travail, ce qui aura pour effet de provoquer de magistrales confrontations entre les syndiqués et les pouvoirs publics. Ultimement, ces restrictions aux conditions de travail des syndiqués du secteur public sont susceptibles de déclencher des mouvements de solidarité parmi les travailleurs (comme on l'a vu avc la coalition pour le droit de négocier au Québec).

Finalement, Thompson et Swimmer suggèrent que plutôt que de restreindre les droits de négocier, les gouvernements devraient faire comme plusieurs entreprises privées ont faites lorsqu'elles étaient en difficultés économiques, c'est-à-dire utiliser la négociation collective pour régler leurs problèmes de relations du travail.

Jean BOIVIN

Université Laval

Worker Capitalism. The New Industrial Relations, by Keith Bradley and Alan Gelb, Cambridge, Mass., The MIT Press, 1983, 186 pp., ISBN 0-262-02191-0

Unemployment in western liberal democracies measures in the tens of millions. Little wonder then that schemes for saving jobs attract considerable attention, even if the number of job savings is disproportionate to the impact of the policy. Despite much publicity from time to time however, employee takeovers, worker co-operatives, and employee ownership schemes still struggle to attain concise theoretical treatment.

Classical economists argue that the declining fortunes of any business enterprise or industrial sector is a necessary part of the ebb and flow of market supply and demand and that attempts to shore up ailing firms will only delay the equilibrium of market forces. Conversely, most Marxist commentators see employee owned ventures as experimental islands of advaneing working class consciousness which will be muddied by the polluted waters of capitalism. They argue that as long as an organization has to borrow and sell according to the market, then it will be forced to conform to capitalist structures, rationale and eventually ideology.

Keith Bradley and Allan Gelb, in their book Worker Capitalism - The New Industrial Relations, have attempted to escape these criticisms, arguing that worker ownership may be «a useful component, in some circumstances, of a program of re-industrialization» (p. 2), and that such a program or rationale «need not be primarily ideological» (p. 2). They set themselves the task of showing that protective policies such as import controls or direct public subsidy are inferior methods by which declining industries, plant closures and the like, can be averted. Instead they advocate, where appropriate, employee ownership as a means of coping with industrial decline and accompanying restructuring. Their arguments are carefully threaded through a number of case studies. Thus, «The approach adopted is a blend of theoretical inference and empirical study, with the objective of isolating commonality and drawing out its relevance for policy" (p. 10). Perhaps of even more importance, they imply that in pluralistic democracies worker takeovers are not unnatural responses to plant closures and that together with traditional sources of support, such initiatives should be "appropriately aided by government» (p. 4). In this way, Bradley and Gelb are offering a temporary marriage of the institu- 
tions of "free enterprise with those of representative democracy» (p. 3). In other words, worker owned enterprises are seen as politically expedient in the short run; presumably in the interest of industrial harmony and the preservation of the social order - a form of industrial Keynesianism.

They identify the post-war move towards greater industrial intervention (a form of social insurance) provided by an increasing network of government regulations and controls, and then offer an explanatory framework with predictive qualities with respect to when spontaneous employee takeovers may occur.

This model, simply stated, suggests that employees are likely to view the possibility of taking over their ailing companies more positively if there is perceived public assistance. Added to this of course is the problem of personal equity constraints, risk taking and the availability of waged employment elsewhere. This model is then tested empirically against cooperative ventures in the U.S., Britain, France and Canada. With less ideological polarisation, pragmatism and emphasise on enterprise viability, it is argued that in the U.S., worker co-operatives are more likely to be successful than in the U.K. where worker's control carries more radical connotation and is therefore less likely to receive government support. (The «Benn» co-operatives at Kirby, Meriden and the Scottish Daily News are described as (anachronisms».)

In essence, what Bradley and Gelb achieved is a useful descriptive overview of why and how employee takeovers take place. In passing, they suggest that such phenomena might form part of an industrial policy which can respond to widespread industrial dislocation. Their review is comprehensive but frustrating. Their is a constant failure to confront fundamental questions which any discourse on worker co-operatives should contain. What illusions are being created here? As the authors themselves admit, less than 100,000 jobs in the U.S. fall into the catagory under discussion. Who bears the costs and the risks? They state that at Tembec, in Canada, «basic hourly wages were to be trimmed by $10 \%$ in $1973,18 \%$ in 1974 and $20 \%$ in 1975. Elimination of shift premium, and cuts in paid holidays, life insurance, pension, indemnity, jury duty and call-in pay as well as other fringe benefits were estimated to reduce total unit labour costs by $24 \%$ in $1973,25 \%$ in 1974 and $27 \%$ by 1975 (p. 112-3). Thus the role played by the workforce, "was to furnish capital at low expected rates of return to the new enterprise to unlock constraints in the labour market experienced by its perspective workforce» (p. 113). Moreover, Bradley and Gelb recognise that actual employee control at Tembec is minimal.

The Meriden motorcycle co-operative in Britain bears a resemblance to Tembec also. Years of under-investment left the Triumph plant at Meriden woefully unequipped to produce modern motorcyles efficiently. In order to drive labour costs down, the workers had little choice but to accept total work flexibility and an across the board wage substantially below the Coventry District rate for engineering plants. Clearly, worker co-operatives must buy and sell in competitive markets. That this leads to employees bearing the financial costs and risks is hardly debatable. Indeed, the authors openly state that such ventures should be seen as purely transitional, until the normal channels of free enterprise can absorb them into traditional forms of capitalist production.

Surely it is the wider issue of why western democracies continually render millions of workers unproductive which should attract our attention rather than minority schemes such as worker owned enterprises. Worker Capitalism, shows how workers can be driven to considerable ends in order to maintain employment and security. But an industrial policy based on 
employee takeovers offers assistance after the horse has bolted. Such suggestions during the years of Reaganomics and Thatcherism seem fanciful. This book is set within narrow technical parameters and in doing so succeeds in illuminating the peaks and pitfalls of employee ownership. Yet it must be said that wider and more fundamental issues are neglected.

Clive H.J. GILSON

St-Francis Xavier University

Work Motivation. Theory, Issues, and Applications, by Craig C. Pinder, Glenview, Ill., Scott, Foresman and Corp., 1984, XIV + 365 pp., ISBN 0-673-15799-7

Human functioning is explainable in the terms of what humans want, how rational they are, and how much they are able and willing to learn. Different theories may be of differential value in understanding and influencing employee behaviour in different types of work situations. This depends on the degree of knowledge an individual has about potential outcomes from his/her acts, as well as on the degree of knowledge the individual has about the nature of the causal relationships that exist, if any, among major elements of that setting. Appropriate reasoning on work motivation will differ accordingly depending on appropriate contingencies. In the ambiguous situations internalized norms and values play a higher motivational role than in the clear situations. According to Pinder, "organizational scientists interested in work motivation have under-emphasized the role of the contexts within which employee motivation is generated and expended".

Levels of task difficulty actual or perceived by the employee depend much on his/her characteristics: ability, state of mind, personality, self-esteem, need for independence. Several organizational characteristics also play much role: quality and quantity of available information, budget, technology (technologically constrained jobs), unionization, organizational dependence, standardization, centralization, role ambiguity, role conflict (inter-role, intersender, person/role, intra-sender). Relationship between performance and rewards may be distorted due to the fixed payment systems, rigid union contracts, seniority rights, task interdependencies, informal pressures, organizational goals inconsistent with paying for performance, personnel turnover, current levels of profitability, personal characteristics of managers and their ability to handle the complex situation. The influence of employee satisfaction from work-related outcomes is much related to the assessment of the nature and strength of a particular employee's needs in any given situation, kinds of reinforcements and punishers available to the manager, and the differences in the perception of rewards and punishments by various employees (equity and equality).

Motivational theories are too general and they need to be considered within a specific context which is a major determinant of the nature, intensity and duration of human behaviour. We need much more research effort to understand better the specific aspects of behavioral contexts that are either reinforcing or punishing. There is a need of a taxonomy of individuals based upon objective (demographic) and intrapsychic factors. Socio-organizational settings have to be differentiated and their impact needs to be evaluated. There is much room for development in all these fields.

Alexander J. MATEJKO

University of Alberta 